\title{
KORELASI \\ INDEKS 20/(C-PEPTIDE PUASA×GLUKOSA DARAH PUASA) DENGAN HOMA-IR UNTUK MENILAI RESISTENSI INSULIN DIABETES MELITUS TIPE 2
}

\author{
Elsi Kelana, Ellyza Nasrul, Rismawati Yaswir, Desywar
}

\begin{abstract}
Abstrak
Resistensi insulin merupakan penurunan respons biologis jaringan terhadap insulin dalam kadar normal. Pada DM tipe 2 terjadi resistensi dan gangguan sekresi insulin. Terdapat indeks baru 20/(C-peptide puasa x glukosa darah puasa) untuk menilai resistensi sekaligus gangguan sekresi insulin. Penelitian bertujuan membuktikan korelasi indeks 20/(C-peptide puasa x glukosa darah puasa) dengan HOMA-IR untuk menilai resistensi insulin pada DM tipe 2 di RSUP. Dr. M. Djamil Padang. Dengan menggunakan sampel darah dari pasien, kadar glukosa darah puasa, insulin puasa dan C-peptide puasa ditentukan. Data yang diperoleh kemudian dianalisis menggunakan korelasi Pearson. Hasil penelitian menunjukkan rerata kadar glukosa puasa 9,83 $(3,53) \mathrm{mmol} / \mathrm{L}$ [177 $(63,54) \mathrm{mg} / \mathrm{dL}]$, insulin puasa 10,58 $(3,61) \mu \mathrm{U} / \mathrm{L}$, dan $C$-peptide puasa $0,97(0,29) \mathrm{nmol} / \mathrm{L}$ dan terdapat korelasi yang sangat kuat dan bermakna secara statistik $(p<0,0001)$ antara indeks 20/(C-peptide puasa $\times$ glukosa darah puasa) dengan HOMA-IR $(r=-0,838)$. Dapat disimpulkan bahwa indeks 20/(C-peptide puasa $x$ glukosa darah puasa) dan HOMA-IR berkorelasi kuat untuk menilai resistensi insulin pada DM tipe 2 di RSUP. Dr. M. Djamil Padang.
\end{abstract}

Kata Kunci: Indeks 20/(C-Peptide Puasa × Glukosa Darah Puasa), HOMA-IR, resistensi insulin, diabetes melitus tipe 2 .

\begin{abstract}
Insulin resistance is a decrease of biological response of the tissues to the normal level of insulin. In type 2 diabetes, there is resistance and impaired of insulin secretion. There is a new index available to assess resistance and impaired of insulin secretion all at once, with the formula 20/(fasting C-peptide $x$ fasting blood glucose). This study aimed to prove the correlation of this new index to the HOMA-IR (Homeostasis model assesment of insulin resistance) in type 2 diabetes at Dr.M.Djamil Padang hospital. Level of fasting glucose, fasting insulin and fasting Cpeptide of blood were measured, followed by statistical data analysis using Pearson correlation test. The result showed the mean of fasting blood glucose, fasting insulin and fasting $C$-peptide were 9.83 (3.53) $\mathrm{mmol} / \mathrm{L}[177$ (63.54) $\mathrm{mg} / \mathrm{dll}], 10.58$ (3.61) $\mu \mathrm{U} / \mathrm{L}$, and 0.97 (0.29) $\mathrm{nmol} / \mathrm{L}$ respectively. There was a strong and statistically significant correlation $(p<0.0001)$ found between the new index and the HOMA-IR ( $r=-0.838)$. To be concluded, the index 20/(fasting C-peptide $x$ fasting blood glucose) and HOMA-IR was strongly correlated to assess insulin resistance in type 2 diabetes at Dr. M. Djamil Padang hospital.
\end{abstract}

Key words : Index 20/(fasting C-peptide x fasting blood glucose), HOMA-IR, insulin resistance, type 2 diabetes.

Afiliasi Penulis : Bagian Patologi Klinik Fakultas Kedokteran Universitas Andalas/ RSUP. Dr. M. Djamil Padang Korespondensi : Elsi Kelana, email: kelanaelsi@gmail.com, HP: 08126766071 


\section{PENDAHULUAN}

Resistensi insulin merupakan penurunan respons biologis jaringan terhadap insulin dalam kadar normal yang bersirkulasi dalam darah. Patofisiologi pasti yang mendasarinya belum diketahui, tetapi resistensi insulin sering dihubungkan dengan defek kerja insulin. ${ }^{1}$ Menurut Soegondo dan Purnamasari $(2009)^{2}$, resistensi insulin adalah suatu kondisi terjadinya penurunan sensitivitas jaringan terhadap kerja insulin sehingga terjadi peningkatan sekresi insulin sebagai bentuk kompensasi sel beta pankreas.

Resistensi insulin ditemukan pada $25 \%$ populasi dewasa. ${ }^{3}$ Penelitian mendapatkan resistensi insulin pada usia lanjut sebanyak 25\%. ${ }^{4}$ Prevalensi resistensi insulin pada pasien sindrom ovarium polikistik di RS. DR. Cipto Mangunkusumo Jakarta sebanyak $75 \%{ }^{5}$

Resistensi insulin berperan penting dalam perjalanan penyakit diabetes melitus tipe 2. Mekanisme resistensi insulin pada diabetes melitus tipe 2 terjadi karena kelelahan sel beta pankreas akibat meningkatkan produksi insulin terus menerus sebagai kompensasi terhadap peningkatan kadar glukosa secara kronis. Kelelahan sel beta pankreas mengakibatkan kadar glukosa darah tetap tinggi walaupun dalam keadaan puasa seperti yang ditemukan pada diabetes melitus tipe 2. 3,6,7 Pada diabetes melitus tipe 2, selain resistensi insulin terjadi juga disfungsi sel beta pankreas. ${ }^{3,6}$

Penelitian mengenai resistensi insulin merupakan hal yang menarik karena berhubungan dengan berbagai macam penyakit termasuk diabetes melitus tipe 2. Pemeriksaan yang menjadi baku emas untuk resistensi insulin adalah euglycemic hyperinsulinemic clamp. Pemeriksaan ini dilakukan dengan menggunakan infus insulin, pengambilan darah beberapa kali, dan membutuhkan tenaga pemeriksa terampil sehingga untuk aplikasi klinis dan penelitian tidak praktis dilakukan. Hal tersebut memicu munculnya banyak penelitian mencari pemeriksaan praktis untuk menilai resistensi insulin. ${ }^{8,9}$

Metode yang banyak digunakan dalam menilai resistensi insulin dan sudah diterima secara luas adalah Homeostasis Model Assesment of Insulin Resistance (HOMA-IR). Dalam metode tersebut dilakukan pemeriksaan kadar insulin dan glukosa puasa, hasilnya dimasukan ke rumus. ${ }^{9,10}$ Penelitian terdahulu melaporkan korelasi HOMA-IR dengan hyperinsulinemic euglycemic clamp. ${ }^{10}$ Penelitian Ohkura et al (2013) mendapatkan korelasi HOMA-IR dengan glucose infusion rate (GIR) $r=0,74 \quad(p<0,005) .{ }^{11}$ Penelitian yang menggunakan HOMA-IR sudah banyak dilakukan baik pada pasien diabetes melitus maupun tidak. ${ }^{12,13,14}$

Penelitian Ohkura et al (2013) mengusulkan indeks baru yang sederhana dan efektif yang dikorelasikan dengan GIR dan didapatkan hasil berkorelasi kuat dan bermakna $(r=0,83$, $p<0,0005)$. Indeks tersebut digunakan untuk menilai resistensi insulin sekaligus menilai fungsi sekresi sel beta pankreas karena memeriksa kadar glukosa puasa dan $C$-peptide puasa. Hasil pemeriksaan dimasukan dalam rumus 20/(C-peptide puasa $x$ glukosa darah puasa). Keunggulan lain dari indeks tersebut 
adalah sangat baik digunakan pada pasien diabetes melitus tipe 2 karena terdapatnya resistensi insulin dan terjadinya gangguan sekresi insulin. Penelitian ini juga mendapatkan pasien dengan nilai GIR 5-10 mg/kg/menit (resistensi insulin ringan) berkorelasi sangat kuat dan bermakna $(r=0,9, p<$ $0,0005)$ dengan baku emas bahkan lebih baik jika dibandingkan dengan HOMAIR. Indeks ini belum banyak diteliti sehingga untuk menerapkan pemakaian indeks tersebut tentu membutuhkan penelitian lain. $^{11}$

Berdasarkan latar belakang diatas, peneliti tertarik melakukan penelitian tentang korelasi indeks 20/(C-peptide puasa $x$ glukosa darah puasa) dengan HOMA-IR untuk menilai resistensi insulin pada diabetes melitus tipe 2 di RSUP. Dr. M. Djamil Padang.

\section{METODE}

Penelitian ini merupakan penelitian analitik dengan rancangan potong lintang. Penelitian dilakukan di Laboratorium Sentral RSUP. Dr. M. Djamil Padang dan Balai Laboratorium Kesehatan Provinsi Sumatera Barat pada Februari- September 2014.

Populasi adalah seluruh pasien diabetes melitus tipe 2 yang sudah didiagnosis oleh klinisi dari rawat jalan dan melakukan pemeriksaan di Laboratorium Sentral RSUP. Dr. M. Djamil Padang. Sampel adalah bagian dari populasi, berumur 40-65 tahun, puasa 8-10 jam sebelum pengambilan darah, dan bersedia menjadi sampel penelitian. Pasien yang sudah dikenal menderita penyakit ginjal, kadar kreatinin serum $\geq 1,2 \mathrm{mg} / \mathrm{dL}$, sudah dikenal menderita penyakit pankreas (pankreatitis, tumor pankreas), pasien mendapat terapi insulin tidak diikutsertakan dalam penelitian.

Bahan pemeriksaan adalah serum yang didapat dari $3 \mathrm{~mL}$ darah vena tanpa antikoagulan. Pemeriksaan kadar glukosa darah langsung dilakukan setelah serum didapatkan. Pemeriksaan kadar insulin dan $C$-peptide dilakukan pada serum yang disimpan pada suhu $-20^{\circ} \mathrm{C}$ sampai jumlah sampel terpenuhi. Metode pemeriksaan glukosa dengan prinsip enzimatik heksokinase sementara insulin dan $C$-peptide diperiksa dengan prinsip Electro chemiluminescence Immunoassay (ECLIA) dengan menggunakan analyzer otomatis.

Data hasil pemeriksaan dikumpulkan secara manual dan diolah menggunakan statistik. Gambaran karakteristik sampel ditampilkan dalam bentuk tabulasi. Korelasi antara indeks 20/Cpeptide puasa $x$ glukosa darah puasa dengan HOMA-IR dianalisis menggunakan uji korelasi Pearson (terdistribusi normal). Korelasi dinyatakan sebagai sangat lemah $(r=0,00-0,19)$, lemah $(r=0,20-0,39)$, sedang $(r=0,40$ - 0,59), kuat $(r=0,60-0,79$, sangat kuat $(r=0,80-1,0)$. Penelitian ini sudah disetujui oleh komite etik RSUP. Dr. M. Djamil Padang.

\section{HASIL DAN PEMBAHASAN}

Penelitian dilakukan secara potong lintang mulai Februari sampai September 2014 dengan jumlah sampel 30. Pasien menggunakan obat hipoglikemik oral yaitu obat golongan biguanid, sulfonilurea, inhibitor aglucosidase. Tidak ada pasien yang 
menggunakan terapi insulin atau obat golongan thiazolidinedion. Parameter yang diperiksa adalah kadar glukosa, insulin, dan C-peptide puasa.

Pemeriksaan sampel dilakukan setelah alat otomatis dikalibrasi. Kalibrasi pemeriksaan glukosa darah puasa menggunakan calibrator for automatic system (C.f.a.s) dan kontrol kualitas menggunakan Precinorm U. Hasil uji ketelitian didapatkan coefficient of variation (CV) within run glukosa puasa adalah $1,54 \%$ dan $C V$ between day adalah $1,69 \%$. Kalibrasi pemeriksaan insulin menggunakan insulin calset dan pemeriksaan $C$-peptide menggunakan C-peptide calset. Hasil uji ketelitian within run pemeriksaan insulin puasa didapatkan CV kontrol PCM1 adalah $1,52 \%$ dan PCM2 adalah 1,70\% dan CV between day kontrol PCM1 adalah $0,58 \%$ dan PCM2 adalah $1,64 \%$. Coefficient of variation within run pemeriksaan $C$-peptide untuk PCM1 = $1,13 \%$ dan $\mathrm{PCM} 2=2,25 \%$ dan $\mathrm{CV}$ between day $\mathrm{PCM} 1=1,47 \%$ dan $\mathrm{PCM} 2$ $=1,15 \%$.

Pengaturan kadar glukosa darah terutama dilakukan oleh jaringan yang sensitif terhadap insulin. Peningkatan kadar glukosa merangsang pelepasan insulin, menyebabkan peningkatan ambilan glukosa sehingga kadar glukosa darah kembali normal. ${ }^{3}$ Pada diabetes melitus tipe 2 terjadi gangguan homeostasis glukosa karena terjadinya gangguan sekresi dan kerja insulin atau keduanya sehingga terjadi hiperglikemia. ${ }^{15}$

Perjalanan penyakit diabetes melitus tipe 2 dimulai dengan terjadinya hiperinsulinemia untuk mengompensasi terjadinya peningkatan kadar glukosa sehingga kadar glukosa tetap dalam batas normal. Jika hal ini terus berlangsung dapat mengganggu fungsi insulin sehingga terjadi resistensi insulin. Pada diabetes melitus tipe 2, resistensi insulin yang terjadi terutama pada postreseptor. Peningkatan produksi insulin secara terus menerus menyebabkan kelelahan pada sel beta pankreas sehingga terjadi gangguan sekresi yang mengakibatkan timbulnya gangguan toleransi glukosa. ${ }^{3,6,7}$

Adanya gangguan toleransi glukosa dan penurunan fungsi sel beta pankreas yang terus menerus menyebabkan terjadinya hiperglikemia postprandial. Hal ini dapat dilihat dari penurunan respons sekresi insulin fase pertama. Jika keadaan ini terus berlanjut akan terjadi gangguan sekresi fase kedua insulin yang ditandai dengan hiperglikemia pada saat puasa. ${ }^{16,17}$

Pada penelitian ini didapatkan keadaan hiperglikemia dalam keadaan puasa dengan rerata kadar glukosa puasa adalah 9,83 $(3,53) \mathrm{mmol} / \mathrm{L}[177$ $(63,54) \mathrm{mg} / \mathrm{dL}]$. Hasil ini berbeda dengan penelitian Saisho et al (2012) yang mendapatkan rerata kadar glukosa puasa $7,94 \quad(1,67) \mathrm{mmol} / \mathrm{L}\left[\begin{array}{ll}143 & (30)\end{array}\right.$ $\mathrm{mg} / \mathrm{dL}$. Perbedaan ini dikarenakan metode penelitian yang di gunakan berbeda. Penelitian Saisho et al mengeksklusi subjek penelitian yang mempunyai kadar glukosa diatas 180 $\mathrm{mg} / \mathrm{dL}$, positif antibodi GAD atau IA-2, dan memasukan sebagai subjek penelitian pasien yang diterapi dengan thiazolidinedion dan insulin ${ }^{18}$ sementara penelitian ini memasukan subjek dengan kadar glukosa diatas $180 \mathrm{mg} / \mathrm{dL}$, dan tidak melakukan pemeriksaan antibodi. 
Tabel 1. Karakteristik Dasar Subjek Penelitian

\begin{tabular}{|c|c|c|}
\hline Variabel & $\mathbf{N}(\%)$ & Rerata (SD) \\
\hline $\begin{array}{l}\text { Jenis Kelamin } \\
\text { Laki-laki } \\
\text { Perempuan }\end{array}$ & $\begin{array}{l}14(46,67) \\
16(53,33)\end{array}$ & \\
\hline Umur (Tahun) & & $57,20(5,40)$ \\
\hline $\begin{array}{l}\text { Indeks Massa Tubuh }\left(\mathrm{kg} / \mathrm{m}^{2}\right) \\
\text { Berat Badan Kurang }(<18,50) \\
\text { Berat Badan Normal }(18,5-24,99) \\
\text { Berat Badan lebih }(\geq 25,00) \\
\text { Preobese }(25-29,99) \\
\text { Obese }(\geq 30) \\
\text { Obese klas I }(30,00-34,99) \\
\text { Obese klas II }(35,00-39,99) \\
\text { Obese klas III }(\geq 40,00)\end{array}$ & $\begin{array}{l}0 \\
12(40) \\
12(40) \\
6(20)\end{array}$ & $26,18(3,76)$ \\
\hline $\begin{array}{l}\text { Lingkar Pinggang }(\mathrm{cm}) \\
\text { Laki-laki } \\
\text { Tidak obesitas sentral }(<90) \\
\text { obesitas sentral }(\geq 90) \\
\text { Perempuan } \\
\text { Tidak obesitas sentral }(<80) \\
\text { Obesitas sentral }(\geq 80)\end{array}$ & $\begin{array}{l}2(6,67) \\
12(40) \\
2(6,67) \\
14(46,66)\end{array}$ & \\
\hline Lama Menderita DM (tahun) & & $6,53(6,17)$ \\
\hline $\begin{array}{l}\text { Riwayat Keluarga Menderita DM } \\
\text { Ada } \\
\text { Tidak Ada }\end{array}$ & $\begin{array}{l}15(50) \\
15(50)\end{array}$ & \\
\hline
\end{tabular}

Pasien yang mendapat terapi insulin diekslusi pada penelitian ini karena akan diperiksa kadar insulin puasa, dan jika tetap dimasukan sebagai subjek penelitian maka akan terjadi kerancuan tentang kadar insulin puasa yang diperiksa. Selain itu pemberian terapi insulin dapat memicu terjadinya pembentukan antibodi terhadap insulin tersebut.

Insulin merupakan hormon yang dihasilkan oleh sel beta pankreas. ${ }^{19}$ Sintesisnya distimulasi jika kadar glukosa $>70 \mathrm{mg} / \mathrm{dL}(>3,9 \mathrm{mmol} / \mathrm{dL}$ ) dan dimulai dari transportasi glukosa ke dalam sel beta pankreas yang menyebabkan terjadinya sekresi insulin. ${ }^{20,21}$ Sekresi insulin terdiri dari dua fase yaitu fase 1 dan fase 2. Fase 1 munculnya cepat dan berakhir juga cepat kemudian diikuti oleh fase $2 .{ }^{19}$ Kadar normal insulin 2-25 $\mu \mathrm{U} / \mathrm{mL}$ (12$150 \mathrm{pmol} / \mathrm{L})$. Insulin yang disekresikan ke sirkulasi akan melewati hepar dan mengalami ekstraksi disana. Sisanya akan berikatan dengan reseptor 
Insulin dan menyebabkan transduksi sinyal intraselular yang menyebabkan masuknya glukosa ke dalam sel. ${ }^{20}$ Sekresi insulin pada pasien diabetes melitus tipe 2 mengalami gangguan. Awalnya terjadi resistensi insulin yang diatasi dengan peningkatan produksi insulin lalu terjadi gangguan toleransi glukosa dan selanjutnya menjadi diabetes melitus tipe 2. ${ }^{3}$ Pada diabetes melitus tipe 2 terjadi gangguan sekresi dan kerja insulin atau keduanya sehingga terjadi hiperglikemia. ${ }^{15}$

Pada penelitian ini didapatkan rerata kadar insulin puasa adalah 10,58 $(3,61) \mu \mathrm{U} / \mathrm{L}$. Rerata kadar insulin puasa ini masih dalam batas nilai normal. Hasil penelitian ini berbeda dengan penelitian Ohkura et al (2013) yang mendapatkan rerata kadar insulin 8,71 (5,72) $\mu \mathrm{U} / \mathrm{L}$ $[60,5(39,7) \mathrm{pmol} / \mathrm{L}]^{11}$, Nguyen et al (2011) mendapatkan rerata kadar insulin $22(1,0) \quad \mu U / m L .^{22}$ Perbedaan yang terjadi kemungkinan berhubungan dengan berbedanya rerata kadar glukosa darah $[7,66(1,29)$ dan 8,61 $(0,11) \mathrm{mmol} / \mathrm{L}]$ pada penelitian tersebut dengan penelitian ini $[9,83 \quad(3,53)$ $\mathrm{mmol} / \mathrm{L}]$. Kadar glukosa darah pada penelitian ini lebih tinggi dibandingkan dengan kedua penelitian tersebut. Kadar glukosa yang tinggi akan merangsang sel beta pankreas untuk menghasilkan insulin dalam kadar yang lebih banyak.

\section{C-peptide merupakan hormon}

yang dihasilkan bersamaan dengan insulin, berasal dari proinsulin yang mengalami pemecahan dan disimpan di granul sekretori sel beta pankreas. Cpeptide berperan penting dalam biosintesis insulin yaitu menghubungkan rantai $A$ dan $B$ sehingga terbentuk ikatan yang kuat dan pembentukan ikatan disulfida antar rantai tersebut. Akibat proses proteolisis proinsulin, C-peptide dilepaskan sehingga bagian $\mathrm{COOH}$ terminal rantai $\mathrm{B}$ insulin menjadi terpapar dan bebas untuk berinteraksi dengan reseptor insulin. C-peptide dihasilkan dalam jumlah yang sama dengan insulin. $^{23}$ Kadar C-peptide lebih tinggi dalam sirkulasi dibandingkan dengan insulin karena tidak atau sedikit mengalami degradasi di hepar sehingga lebih menggambarkan sekresi insulin endogen. 6 24, 25 Kadar normal C-peptide puasa adalah $0,25-0,6 \mathrm{nmol} / \mathrm{L}(0,78-1,89$ $\mathrm{ng} / \mathrm{mL})$.

Pada diabetes melitus tipe 2 terjadi defek sekresi dan kerja insulin atau keduanya. ${ }^{15}$ Defek sekresi ini berhubungan dengan disfungsi sel beta pankreas yang dapat disebabkan oleh banyak faktor seperti penurunan massa sel beta, peningkatan apoptosis /penurunan regenerasi sel, kelelahan sel beta karena resistensi insulin yang lama, toksisitas glukosa, toksisitas lipid pada sel beta, inflamasi, dan deposisi amiloid atau kondisi lain yang dapat menurunkan massa sel beta. ${ }^{6,26}$

Rerata kadar C-peptide puasa pada penelitian ini adalah 0,97 $(0,29)$ $\mathrm{nmol} / \mathrm{L}$. Hasil ini lebih tinggi jika dibandingkan dengan nilai normal, sehingga dapat disimpulkan pada subjek penelitian ini sekresi insulin endogen meningkat karena kadar $C$-peptide lebih menggambarkan sekresi insulin endogen daripada hasil pemeriksaan insulin itu sendiri. Peningkatan kadar C-peptide dapat merupakan kompensasi dari peningkatan kadar glukosa puasa yang meningkat pada subjek penelitian ini. Kadar glukosa yang meningkat akan menstimulasi sel beta pankreas untuk 
meningkatkan produksi hormonnya. Peningkatan kadar C-peptide puasa pada penelitian ini juga menunjukkan lebih dominannya gangguan fungsi insulin (resistensi insulin) dibandingkan dengan gangguan sekresi insulin.

Hasil penelitian ini sedikit berbeda dengan penelitian Chung et al (2010) di Korea yang mendapatkan rerata kadar C-peptide puasa $0,90(0,54) \mathrm{nmol} / \mathrm{L}^{27}$, tetapi berbeda dengan penelitian Saisho et al (2012) yang mendapatkan rerata kadar C-peptide adalah 0,57 $(0,333)$ $\mathrm{nmol} / \mathrm{L}[1,71(1,00) \mathrm{ng} / \mathrm{mL}] .^{18}$ Perbedaan yang terjadi kemungkinan berhubungan dengan berbedanya kadar glukosa pada penelitian tersebut dan kriteria inklusi serta ekslusi subjek penelitian.

Pada penelitian Saisho et al $(2012)^{18}$ didapatkan rerata kadar glukosa puasa adalah $7,94(1,67) \mathrm{mmol} / \mathrm{L}[143$ (30) $\mathrm{mg} / \mathrm{dL}$ ] sedangkan penelitian ini mendapatkan rerata kadar glukosa darah puasa adalah $9,83(3,53) \mathrm{mmol} / \mathrm{L}$ [177 $(63,54) \mathrm{mg} / \mathrm{dL}]$. Penelitian Saisho et al ini mengeksklusi subjek penelitian yang mempunyai kadar glukosa diatas $180 \mathrm{mg} / \mathrm{dL}$ dan kadar kreatinin serum $\geq 2$ $\mathrm{mg} / \mathrm{dL} .^{18}$ Penelitian ini memasukan subjek dengan kadar glukosa diatas 180 $\mathrm{mg} / \mathrm{dL}$ dan mengekslusi kadar kreatinin serum $\geq 1,2 \mathrm{mg} / \mathrm{dL}$. Kadar glukosa yang tinggi menyebabkan perangsangan yang lebih kuat pada sel beta pankreas untuk memproduksi $C$-peptide dalam jumlah yang lebih banyak sehingga hasil kadar $C$-peptidenya lebih tinggi. Kemungkinan lain yang menyebabkan perbedaan hasil ini adalah berbedanya kadar kreatinin serum pada subjek penelitian. Hal ini berhubungan dengan bersihan $C$-peptide terjadi di ginjal, walaupun sampai saat ini belum didapatkan kepustakaan yang menyatakan hubungan kadar kreatinin serum dengan $C$-peptide.

Indeks 20/ (C-peptide puasa $\mathrm{x}$ glukosa darah puasa) merupakan indeks baru yang diajukan oleh penelitian Ohkura et al (2013). Keunggulan lain selain yang telah disebutkan sebelumnya adalah dimasukannya pemeriksaan $C$-peptide ke dalam rumus tersebut. ${ }^{11}$ Seperti yang diketahui bahwa $C$-peptide merupakan penanda sekresi insulin endogen yang lebih baik dibandingkan insulin, mempunyai waktu paruh yang lebih panjang dibandingkan insulin, tidak atau sangat sedikit diektraksi oleh hepar. Pada diabetes melitus tipe 2 yang terjadi bukan hanya resistensi insulin tetapi juga dapat ditemukan defek sekresi insulin sehingga dengan menggunakan indeks ini pada diabetes melitus tipe 2 selain dapat menilai resistensi insulin juga menilai fungsi sel beta pankreasnya.

Hasil penelitian ini mendapatkan korelasi antara indeks 20/C-Peptide puasa $\mathrm{x}$ glukosa darah puasa dengan HOMA - IR menggunakan SPSS 15.0 didapatkan hasil $r=-0,838$ dengan $\mathrm{p}<0,0001$ (Gambar 1). Pada Gambar terlihat makin tinggi nilai indeks makin rendah nilai HOMA-IR, secara statistik terdapat korelasi yang sangat bermakna dan signifikan.

Penelitian mengenai korelasi indeks 20/(C-peptide puasa x glukosa darah puasa) dengan HOMA-IR untuk menilai resistensi insulin pada DM tipe 2 belum ada sebelumnya. Pada penelitian ini didapatkan rerata indeks $20 /(C$ peptide puasa $\times$ glukosa darah puasa) adalah 2,46 $(0,81)$ dan rerata HOMA-IR adalah 4,48 (1,96). Hasil ini berbeda dengan penelitian Ohkura et al (2013) 


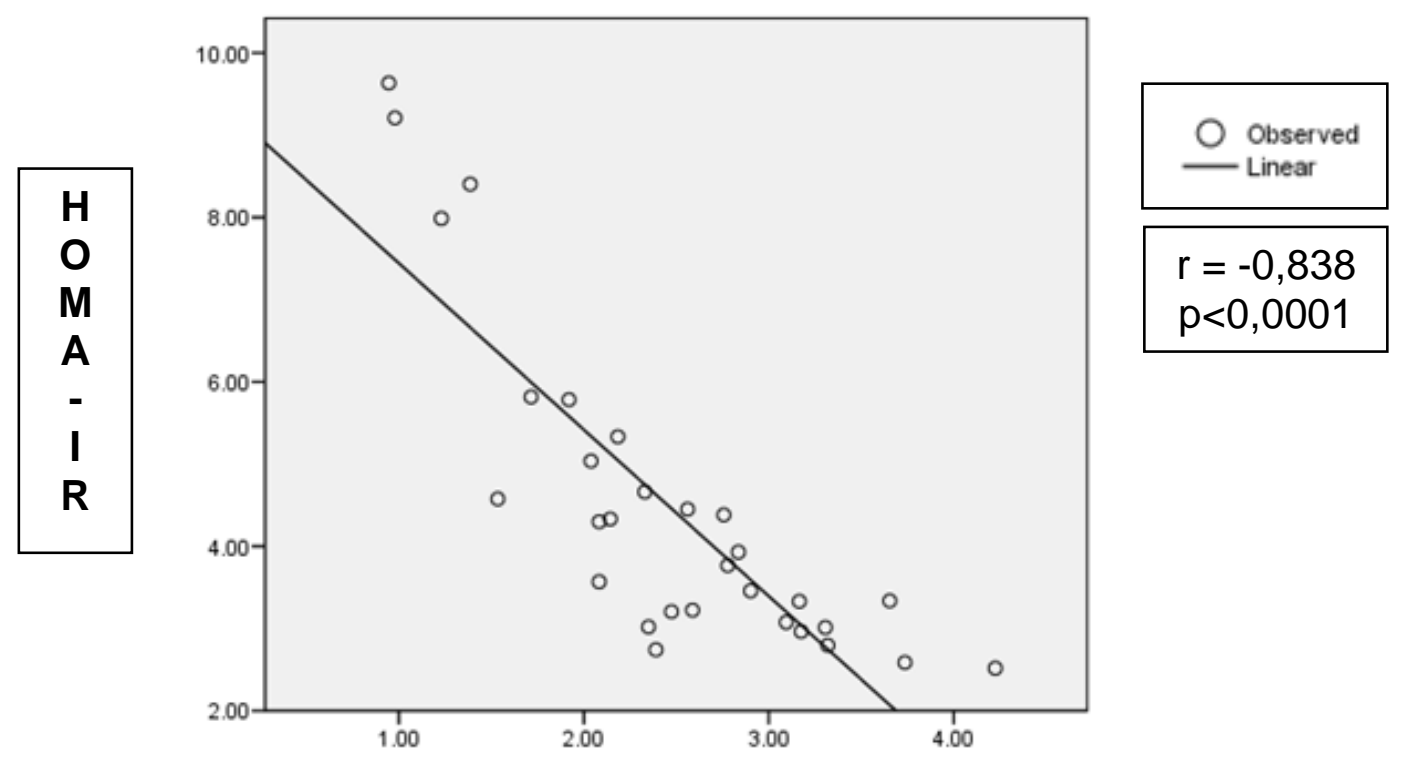

INDEKS

\section{Gambar 1. Korelasi Indeks 20/C-Peptide Puasa x Glukosa Darah Puasa dengan HOMA-IR}

yang mendapatkan rerata indeks $20 /(C$ peptide puasa $\times$ glukosa darah puasa $)=$ $5(2,00)$ dan HOMA-IR $=2,9(1,84) .{ }^{11}$

Hasil ini menunjukkan subjek penelitian ini mempunyai resistensi insulin yang lebih tinggi jika dibandingkan dengan subjek penelitian Ohkura et al (2013). Hal ini didukung oleh data kadar $C$-peptide pada penelitian ini lebih tinggi jika dibandingkan dengan kadar $C$ peptide pada penelitian Ohkura et al $\left[\begin{array}{lllll}0,97 & (0,29) & \mathrm{nmol} / \mathrm{L} & ><0,60 & (0,25)\end{array}\right.$ $\mathrm{nmol} / \mathrm{L}]$. Kadar $C$-peptide yang tinggi menunjukkan sel beta pankreas lebih aktif untuk menghasilkan hormonnya.

Penyebab terdapatnya perbedaan antara hasil penelitian ini dengan penelitian Ohkura et al adalah berbedanya kadar glukosa, insulin, dan C-peptide. Pada penelitiannya, Ohkura et al., mendapatkan rerata kadar glukosa puasa $7,66(1,29)(\mathrm{mmol} / \mathrm{L})$, insulin 60,5 $(39,7) \mathrm{pmol} / \mathrm{L}[8,71(5,72) \mu \mathrm{U} / \mathrm{L}]$, dan $C$ peptide $0,60(0,25) \mathrm{nmol} / \mathrm{L}$ sedangkan pada penelitian ini rerata kadar glukosa, insulin, dan $C$-peptide puasa secara berturut-turut adalah $9,83(3,53) \mathrm{mmol} / \mathrm{L}$, $10,58 \quad(3,61) \quad \mu \mathrm{U} / \mathrm{L}$, dan $0,97 \quad(0,29)$ $\mathrm{nmol} / \mathrm{L}$. Perbedaan kadar tersebut jika dimasukan ke dalam rumus menghasilkan angka yang berbeda juga. Penyebab terjadinya resistensi insulin dan gangguan fungsi sel beta pankreas merupakan multifaktorial seperti penurunan massa sel beta, peningkatan apoptosis/penurunan regenerasi sel, kelelahan sel beta karena resistensi insulin yang lama, toksisitas glukosa, toksisitas lipid pada sel beta, inflamasi, dan deposisi amiloid atau kondisi lain yang dapat menurunkan massa sel beta. $^{6,26}$ Pada penelitian ini tidak memeriksa hal-hal yang berhubungan 
dengan faktor diatas seperti mengukur massa sel beta, kadar lipid, penanda inflamasi yang merupakan keterbatasan dalam penelitian ini.

\section{SIMPULAN}

Berdasarkan hasil penelitian dan pembahasan didapatkan kesimpulan kadar glukosa dan C-peptide puasa meningkat dari nilai normal, kadar insulin puasa dalam batas normal, dan terdapat korelasi yang sangat kuat antara indeks 20/(C-peptide puasa $\times$ glukosa darah puasa) dengan HOMA-IR pada DM tipe 2 di RSUP. Dr. M. Djamil Padang.

\section{DAFTAR RUJUKAN}

1. Sacks DB. Carbohydrates. In Burtis CA, Ashwood E R, Bruns DE, edit, Tietz Textbook of Clinical Chemistry and Molecular Diagnostics, $4^{\text {th }}$ ed, USA, Elsevier Saunders 2006:837-901

2. Soegondo S, Purnamasari D. Sindrom Metabolik. Dalam Buku Ajar IImu Penyakit Dalam, Jilid III. Sudoyo AW, Setiyohadi B, Alwi I, Simadibrata M, Setiati S, editor, Edisi V, 2009:1865-72

3. DeFronzo RA. Pathogenesis of type 2 diabetes mellitus. Med Clin North Am 2004;88(4):787-835

4. Roosheroe, AG, Setiati, S, Istanti, R. Insulin Resistance as One of Indicators for Metabolic Syndrome and Its Associated Factors in Indonesian Elderly. Acta Med Indones - Indones J Intern Med 2012;44(3): 199-206

5. Wiweko B, Mulya R. Profil Resistensi Insulin pada Pasien Sindrom Ovarium Polikistik (SOPK) di RS Dr. Cipto Mangunkusumo Jakarta. Maj Obstet Ginekol Indones 2008;32(2):93-8

6. Neutzsky-Wulff AV, Andreassen KV, Hjuler ST. Future detection and monitoring of diabetes may entail analysis of both $\beta$-cell function and volume: How markers of $\beta$-cell loss may assist. J Transl Med 2012;10(214):1-16

7. Tsatsoulis A, Mantzaris MD, Bellou S, Andrikoula M. Insulin resistance: An adaptive mechanism becomes maladaptive in the current environment an evolutionary perspective. Metab Clin Exp 2013; 62(5):622-33

8. Cefalu WT. Insulin Resistance: Cellular and Clinical Concepts. Exp Biol Med 2001; 226(1):13-26

9. Singh B, Saxena A. Surrogate Markers of Insulin Resistance: A review. World J Diab 2010;1(2):36-47

10. Radikova Z. Assessment of Insulin Sensitivity/Resistance in Epidemiological Studies. Endocrine Regulations 2003;37:189-94

11. Ohkura $T$, Shiochi $H$, Fujioka $Y$ et al. 20/(Fasting C-Peptide $\times$ Fasting Plasma Glucose) is A Simple and Effective Index Of Insulin Resistance In Patients With Type 2 Diabetes Mellitus: A Preliminary Report. Cardiovasc Diabetol 2013;12:(21):1-8

12. Katsuki A, Sumida $Y$, Gabazza EC et al. Homeostasis Model Assessment Is A Reliable Indicator Of Insulin Resistance During Follow-Up Of Patients With Type 2 Diabetes. Diab Care 2001; 24(2):3625

13. Ray S, Bairagi AK, Guha $S$ et al. A Simple Way to Identify Insulin Resistance in Non-Diabetic Acute Coronary Syndrome Patients with Impaired Fasting Glucose. Indian J Endocrinol Metab 2012;16(S2):460-4

14. Yin $\mathrm{J}, \mathrm{Li} M, X \mathrm{X} L$ et al. Insulin Resistance Determined By Homeostasis Model Assessment (HOMA) and Associations with Metabolic Syndrome Among Chinese Children and Teenagers. Diabetol Metab Syndrom 2013; 5(71):1-9

15. American Diabetes Association. Diagnosis and Classification of Diabetes Mellitus. Diab Care 2010; 33(S1): $62-9$ 
16. Gerich JE. Contributions of InsulinResistance and Insulin-Secretory Defects to the Pathogenesis of Type 2 Diabetes Mellitus. Mayo Clin Proc 2003;78(4):447-56

17. Codario RA. Pathophysiology of Type 2 Diabetes", in: Type 2 Diabetes, PreDiabetes, and the Metabolic Syndrome. The Primary Care Guide to Diagnosis and Management, Humana Press Inc 2005;1-10

18. Saisho Y, Tanaka K, Abe T, Shimada A, Kawai $\mathrm{T}$, Itoh $\mathrm{H}$. Effect of Obesity on Declining Beta Cell Function After Diagnosis of Type 2 Diabetes: A Possible Link Suggested By CrossSectional Analysis. Endocrine J 2012; 59(3):187-95

19. Wilcox G. Insulin and Insulin Resistance. Clin Biochem Rev 2005; 26(5):20-39

20. Power AC. Diabetes Mellitus. In Kaper DL, Fauci A. S, Longo DL et al. Harrison's Principles of Internal Medicine, $16^{\text {th }}$, Chapter 323, USA; McGraw-Hill 2005:2152-8

21. Manaf A. Insulin: Mekanisme Sekresi dan Aspek Metabolisme. Dalam Sudoyo AW, Setiyohadi B, Alwi I, Simadibrata M, Setiati S, editor, Buku Ajar IImu Penyakit Dalam Jilid III, Edisi V 2009:1896-9

22. Nguyen NT, Nguyen XMT, Lane J, Wang P. Relationship Between Obesity and Diabetes in a US Adult Population: Findings from the National Health and Nutrition Examination Survey, 19992006. Obes Surg 2011; 21(3):351-5

23. Wahren J, Ekberg $\mathrm{K}$, Johansson $\mathrm{J}$, et al. Role Of C-Peptide In Human Physiology. Am J Physiol Endocrinol Metab 2000; 278(5):E759-68

24. Khan MI, Weinstock RS. Carbohydrates. In McPherson R, Pincus MR, edit. Henry's Clinical Diagnosis and Management by Laboratory Methods, $21^{\text {th }}$ edition, chapter 16. Philadelphia; Elsevier 2007:185-97
25. Steiner DF. The Proinsulin C-peptide-A Multirole Model. Experimental Diab Res 2004;5(1):7-14

26. Kahn SE. Clinical Review 135: The Importance Of B-Cell Failure In The Development And Progression Of Type 2 Diabetes. J Clin Endocrinol Metab 2001; 86(9):4047-58

27. Chung JO, Cho DH, Chung DJ, Chung MY. Plasma C-peptide Level Is Inversely Associated with Family History Of Type 2 Diabetes in Korean Type 2 Diabetic Patients. Endocrine J 2010; 57 (10):931-8 